\title{
STABILIZATION OF BLACK COTTON SOIL USING IRON ORE TAILING
}

\author{
Supritha D K $\mathbf{1}^{\mathbf{1}} \mathbf{J}$ Ranjitha ${ }^{2}$, Kavya U $\mathbf{S}^{\mathbf{3}}$, Puneeth $\mathbf{B}^{\mathbf{4}}$ \\ ${ }^{1}$ Assistant Professor, Civil Engineering, DSCE, Karnataka, India \\ ${ }^{2}$ Assistant Professor, Civil Engineering, DSCE ,Karnataka, India \\ ${ }^{3} U G$ Student, Civil Engineering, DSCE, Karnataka, India \\ ${ }^{4} U G$ Student, Civil Engineering, DSCE, Karnataka, India
}

\begin{abstract}
The Black cotton Soil can be replaced with stronger material in order to improve its stability .Based Indian Council of Agricultural Research (ICAR) the soils of our country are classified as, alluvial soils, black soils, red soils, laterite soils, desert soils, mountain soils, saline and alkaline soils and peaty and marshy soils. Among these soils Black cotton soils are clayey soil having high compressibility and form a major soil group in our country. The characteristics of soil are high shrinkage and swelling properties. This clay soils found mostly in the central, southern and western parts of India. Because of its highly swelling and shrinkage characteristics, construction of roads on the Black cotton soils have become a challenge to the highway engineers. This Black cotton soil becomes very hard when dry, but loses its strength completely when in wet condition. Soil stabilization is a technique introduced many years ago with the main purpose of improving the soil capacity of meeting the requirement of engineering projects. The soil stabilization technique are used to obtain improve the geotechnical properties soil by adding the material such as lime, cement or industrial by-products such as fly ash, geo polymer etc In this project work an attempt is made to improve the engineering properties of Black cotton soil by industrial products such as iron ore tailings. Here we are using IOT as soil stabilizer
\end{abstract}

Keywords: Black cotton soil, Stabilization and Iron Ore Tailings etc...

$* * *$

\section{INTRODUCTION}

Black cotton soils are soils that expand when it becomes wet it gets expand and when it becomes dry it gets shrink. This continuous expansion and contraction will decreases its strength.,. Foundation with swelling soil will heave and can cause lifting of a building or structure laid on it whenever the moisture content rises.

expansive soil consists of mineral like smectite, bentonite, montmorillonite, beidellite, vermiculite, attapulgite, nontronite, illite and chlorite. There are some amount of sulfate salts which will expand due to changes in temperature. Soil containing above mentioned expansive minerals, they tend to possess significant expansion or swelling.

Iron ore tailings which is the waste products of mining industries is used as an alternative to the river sand in the manufacturing of concrete. The KIOCL company which is one of the growing company in our country in mining of iron ore. This company used to dumpat lakya dam around 200 million at metric tons of iron ore tailings . TheKIOCL company has conducted mining for more than 25 years in Kudremukh. The company has stopped mining in 2005 ,

\section{MATERIALS}

Iron ore tailing which is having bulk density $1594 \mathrm{~kg} / \mathrm{m} 3$ and the fineness modulus 2.53 was used in the project work . The specific gravity of the IOT was found to be 2.85 and which is suitable for concrete works. The gradation of the used particles falls within the fine aggregates

Table -1: IRON ORE TAILING'S (IOT) CHEMICAL COMPOSITION

\begin{tabular}{|l|l|l|l|l|l|l|}
\hline Minerals & & $\mathrm{SiO} 2$ & $\mathrm{CaO}$ & $\mathrm{Al} 2 \mathrm{O} 3$ & $\mathrm{MgO}$ & $\mathrm{TiO} 2$ \\
\hline $\begin{array}{l}\text { Composit } \\
\text { ion (\%) }\end{array}$ & 47.70 & 45.64 & 0.607 & 3.26 & 0.393 & 0.240 \\
\hline
\end{tabular}

Design of tailings disposal can be carried out without an appreciation of the physical nature and chemical characteristics of the iron ore tailings. Plant effluent, physicchemical properties of the material dictate on the most fundamental level, the type of disposal facility required and the degree of conservation in its design, consistent with the hazards posed by the materials understanding of tailing effluent involves knowledge of the processes through which they are produced. 
Table -2: PHYSICAL PROPERTIES OF IOTs

\begin{tabular}{|l|l|}
\hline PROPERTY & \\
\hline Specific gravity & 3.33 \\
\hline Water absorption & 3.97 \\
\hline Moisture content\% & 6 \\
\hline Fineness modulus & 2.545 \\
\hline
\end{tabular}

\section{METHODOLOGY}

The following laboratory tests have been carried out according to the specification of IS: 2720.

- Specific Gravity

- Particle Size distribution

- Liquid limit

- Plastic limit

- Shrinkage limit

- Compaction

- Unconfined compression test

- $\mathrm{CBR}$

Table-3: COMBINATION DIFFERENT PERCENTAGE OF IOT'S AND SOIL

\begin{tabular}{|c|c|c|c|}
\hline SLNO & Mix & $\begin{array}{c}\text { SOIL BY } \\
\text { WEIGHT }\end{array}$ & $\begin{array}{c}\text { IOTs BY } \\
\text { WEIGHT }\end{array}$ \\
\hline 1 & MIX-1 & $90 \%$ & $10 \%$ \\
\hline 2 & MIX-2 & $85 \%$ & $15 \%$ \\
\hline 3 & MIX-3 & $80 \%$ & $20 \%$ \\
\hline
\end{tabular}

- Each percentage blend is tested for determining the density, optimum moisture content, CBR and UCC. Likewise the total tests carried are 63 in number and soaked tests of 6 are also carried out.

- By collecting the results of all these blends and comparison of the best suitable additive mix will be done

- Suitable blend mix designed for the flexible pavement according to the IRC-37(design of flexible pavement) and thickness of the pavement have been decided with and without stabilization for black cotton soil is compared.

The results are concluded suitably

\subsection{Sample Preparation}

- Measure the initial length and diameter of the mould specimen.

- Keep the mould on the bottom plate of the loading device.

- Adjust the upper plate such that the upper layer makes contact with the specimen.
- Adjust proving ring and dial gauge to zero.

- Compress the specimen until cracks have definitely developed on the surface of the specimen.

- Take the reading approximately.

The above mentioned test is conducted by adding the stabilizing agents like IOTs in different percentages like $10 \%, 15 \%$ and $20 \%$. Soil sample as brought from the field is dried in the air or in sun. The clods are broken with the help of suitable instrument to hasten drying. The organic matter, such as tree roots and pieces of bark were removed from the soil sample. The soil sample is kept in oven for drying at a $110^{\circ} \mathrm{C}-115^{\circ} \mathrm{C}$ temperature for $24 \mathrm{hrs}$. following basic test was conducted on the soil sample such as liquid limit, plastic limit, light compaction the sample was air dried.:

- Firstly black cotton soil and IOTs are oven dried.

- Required quantities of soil and IOTs are calculated by weight and the quantities are measured.

- Soil and IOTs are mixed thoroughly in dry form.

- Required percentage of water or OMC is added

- And mixed properly.

- Mixed soil is placed in mould.

- For the blend mix with cement and lime, all the materials are taken in dry form and mechanically mixed, later tests were conducted. Soil Sample may be prepared by compacting the soil at the desired water content and dry density in a compaction mould and then cut by the sampling tube.

\section{RESULTS}

Table -4: COMPACTION TEST RESULTS FOR ADDDITIONIRON ORE TAILING'S (IOTs) FOR BLACK COTTON SOIL (BCS)

\begin{tabular}{|l|l|l|l|}
\hline Designation & Mixture & OMC(\%) & $\begin{array}{l}\text { MDD(g/ } \\
\mathrm{cc})\end{array}$ \\
\hline MIX-1 & BCS & 20.5 & 1.603 \\
\hline MIX-3 & BCS+10\% & 21.54 & 1.67 \\
\hline MIX-4 & BCS+15\% & 19.87 & 1.732 \\
\hline MIX-5 & BCS+20\% & 15.84 & 1.784 \\
\hline
\end{tabular}

The compaction test was conducted according to IS 2720 (Part 7) code. The density of native black cotton soil (BCS) is $16.03 \mathrm{KN} / \mathrm{m}^{3}$, on further addition of IOTs in 10,15 and 20 percentages yielded significant changes in MDD and OMC comparison

- The tested soil for compression test possess the unconfined maximum dry density of 1.603 .

- Addition of iron ore tailings, with a percentage of 10,15 and $20 \%$ increases the MDD of the plain soil as follows..... 
Natural soil< $10 \%$ IOTs soil < $15 \%$ IOTs soil < $20 \%$ IOTs1.603,1.67,1.732 and 1.784 respectively

- Due to the reduction in the available soil portion (which absorbs more water due to its clayey and silty nature) to absorb moisture content completely is less, due to the replacement of eliminated soil portion by iron ore tailings, make soil portion denser. And requires less water to become denser and strengthy.

Natural soil< $10 \%$ IOTs soil $>15 \%$ IOTs soil $>$

$20 \%$ IOTs $20.5,21.54,19.87$ and 15.84 respectively

Table -5: UCS TEST RESULTS FOR ADDITION OF IRON ORE TAILING'SFOR BCS

\begin{tabular}{|l|l|l|l|}
\hline SL & Designation & Mixture & $\begin{array}{c}\mathrm{UCC} \\
\left(\mathrm{N} / \mathrm{mm}^{2}\right)\end{array}$ \\
\hline 1 & MIX-1 & BCS & 0.038 \\
\hline 2 & MIX-3 & BCS+10\% & 0.056 \\
\hline 3 & MIX-4 & BCS+15\% & 0.062 \\
\hline 4 & MIX-5 & BCS+20\% & 0.064 \\
\hline
\end{tabular}

\subsection{Comparison}

- The tested soil for unconfined compression test possess the unconfined compression strength of 0.038 .

- Addition of iron ore tailings, with a percentage of 10,15 and $20 \%$ increases the unconfined compressive strength of the plain soil as fallows.....

Natural soil soil $<10 \%$ IOTs soil $<15 \%$ IOTs soil $<20 \%$ IOTs $0.038,0.056,0.062$ and 0.064

Table -6: CBR TEST RESULTS FOR ADDITION OF IRON ORE

\begin{tabular}{|c|c|c|c|}
\hline \multirow{2}{*}{ Designation } & \multirow{2}{*}{ Mixture } & \multicolumn{2}{|c|}{ CBR value } \\
\cline { 3 - 4 } & & $2.5 \mathrm{~mm}$ & $5 \mathrm{~mm}$ \\
\hline MIX-1 & BCS & 10.2 & 8.7 \\
\hline MIX-3 & BCS+10\% & 9.8 & 8.7 \\
\hline MIX-4 & BCS+15\% & 8.4 & 6.6 \\
\hline MIX-5 & BCS+20\% & 6.6 & 5.6 \\
\hline
\end{tabular}

\section{TAILING'S FOR BCS}

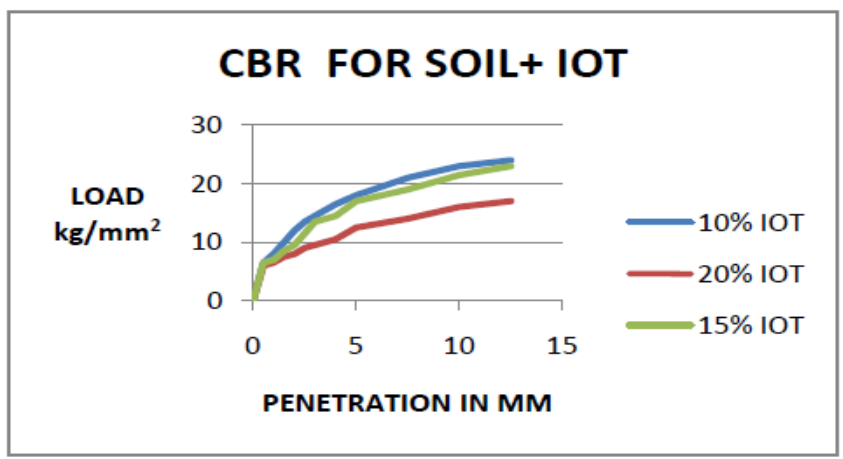

\section{CONCLUSION}

The following are the conclusions can be drawn from the experimental results on Black Cotton Soil stabilized with IOTs:

1. The specific Gravity of the soil for construction purpose should be 2.6 to 2.8 , whereas the Black Cotton soil of this project had a specific gravity of 2.45 . Through experiments by addition of stabilizing agents like IOTs in quantities like 10\%, 15\% and $20 \%$ has showed the increase in specific gravity of the soil to 2.49 , 2.62 , and 2.81 respectively.

2. The liquid limit of the soil should be less for construction purpose. Black Cotton Soil of this project had a liquid limit of $60 \%$ initially. Further by addition of stabilizing agents like IOTs in percentages like 10\%, 15\% and 20\%.

3. The shrinkage limit is the main factor responsible for volume changes in soil. The Black Cotton soil exhibits drastic changes in its volume when exposed to water. The shrinkage limit of the Black cotton soil of this project was $12.87 \%$ further by addition of stabilizing agents like IOTs in percentages like $10 \%, 15 \%$ and $20 \%$ the shrinkage limit of the soil was reduced to $11.78 \%, 11.25$ and 10.85 respectively.

4. The Black Cotton soil was subjected to compaction test by light compacting mould and found out the Maximum Dry Density (MDD) and Optimum Moisture Content obtained is $1602.91 \mathrm{Kg} / \mathrm{m}^{3}$ and $20.5 \%$.

5. The soil for construction purpose should have good load bearing characteristics. This load baring capacities was determined by Unconfined Compression Strength test. The soil of this project had strength of $0.038 \mathrm{~N} / \mathrm{mm} 2$. By addition of stabilizing agents IOTs in percentages like $10 \%, 15 \%$ and $20 \%$ the results obtained are $0.056 \mathrm{~N} / \mathrm{mm} 2$, $0.062 \mathrm{~N} / \mathrm{mm} 2$ and $0.065 \mathrm{~N} / \mathrm{mm} 2$ respectively.

6. Here it can be observed that the compressive strength was increasing up to addition of stabilizing agent till 25\% on further addition there will be decrease in the soil strength.

7. The BCS used for CBR test is achieved strength $10.2 \%$ at $2.5 \mathrm{~mm}$ and $8.7 \%$ at $5 \mathrm{~mm}$ deflection, using IOTs strength achieved gradually decreased at 10,15,20\% additions.

8. Finally it can be concluded that the stabilizing agents like IOTs will help in increasing the mechanical properties of the Black Cotton soil like, liquid limit, shrinkage limit, compaction characteristics and unconfined compressive strength. 


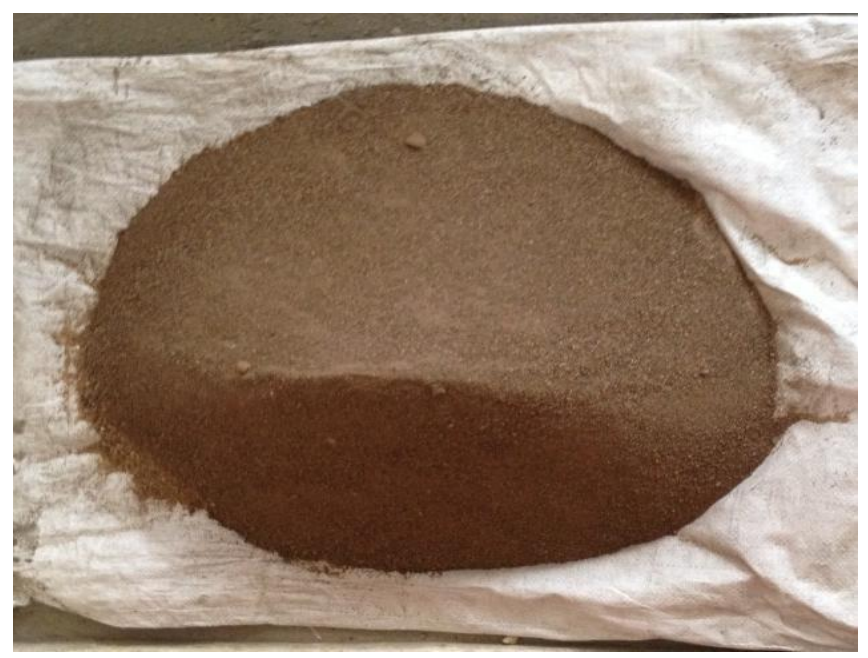

Fig -1: IOT

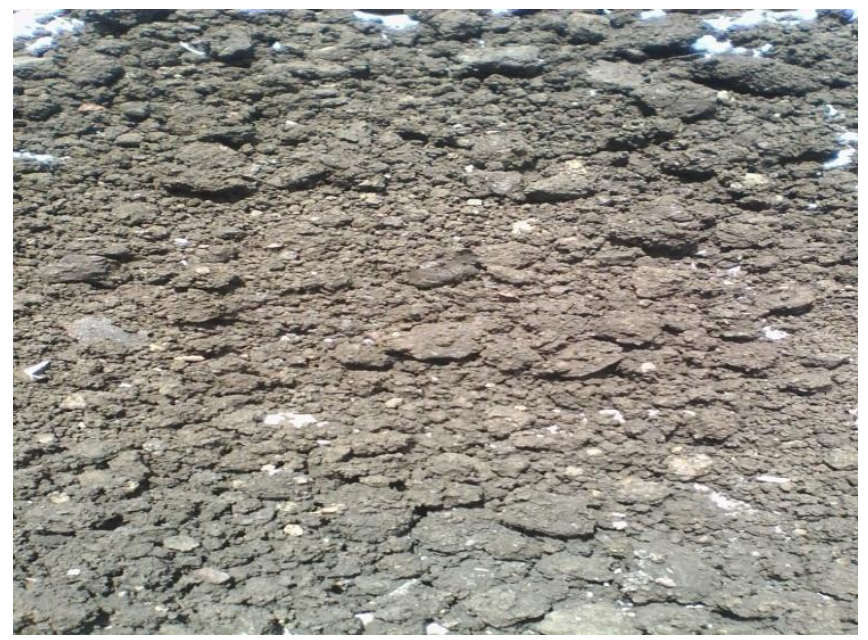

Fig-2: BCS

\section{REFERENCES}

[1]. Aravindkumar.B.Harwalkar and Dr.S.S.Awanti "Fatigue Behavior Of High Volume Fly Ash Concrete Under Constant Amplitude And Compound Loading" International Journal of Civil Engineering and Technology (IJCIET),Volume 3, Issue 2,pp.404-414, July- December 2012.

[2]. Ayrton V. Costa, Adriana G. Gumieri "Use of SinterFeed Tailings as Aggregate in Production of Concrete Paving Elements" Sustainable construction materials and technologies (2010).

[3]. K. P. Nagaraja, K. U. Muthu, A. Veeraragavan "Flexural Fatigue strength of HVFA concrete" ICCBT 2008- C-(38)pp415-424.

[4]. Md. Safiuddin, MohdZaminJumaat, M. A. Salam, M. S. Islam and R. Hashim "Utilization of solid wastes in construction materials" International Journal of the Physical Sciences Vol. 5(13), pp. 1952-1963, 18 October, 2010

[5]. Mohan Yellishetty, Vanda Karpe, E.H. Reddy, K.N. Subhash, P.G. Ranjith "Reuse of iron ore mineral wastes in civil engineering constructions: A case study" Resources, Conservation and Recycling 52, pp.1283-1289, (2008).

[6]. Ravi Kumar C. M, Anil Kumar, Prashanth. M. H and D. Venkat Reddy "Experimental Studies on Iron-Ore Tailing based Interlocking Paver Blocks"

[7]. Sanjay Kumar, Rakesh Kumar, AmitavaBandopadhyay "Innovative methodologies for the utilisation of wastes from metallurgical and allied industries" Resources, Conservation and Recycling 48, pp.301-314, (2006).

[8]. SujingZhao ,Junjiang Fan, Wei Sun "Utilization of iron ore tailings as fine aggregate in ultra-high performance concrete", Construction and Building Materials 50, pp.540548, (2014)

[9]. Vipul D. Prajapati, Nilay Joshi, Prof. JayeshkumarPitroda "Techno- Economical Study of Rigid Pavement by Using the Used Foundry Sand", International Journal of Engineering Trends and Technology (IJETT) - Vol.4 Issue5 May 2013 [10]. Xiaoyan Huang; Ravi Ranade and Victor C. Li,

F.ASCE "Feasibility Study of Developing Green ECC Using Iron Ore Tailings Powder as Cement Replacement" Journal Of Materials In Civil Engineering 25:923-931(2013)

\section{BIOGRAPHIES}

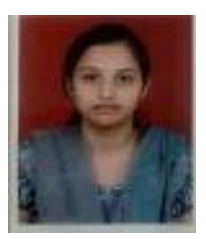

Mrs. Supritha D K, Asst. Prof., Dept. of Civil Engg., Dayananda Sagar College of Engineering, Bengaluru-560078

Email Id: suprithagrantha@gmail.com

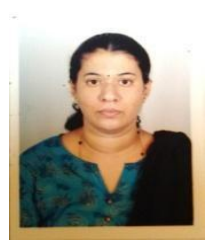

Mrs. J.Ranjitha, Asst. Prof., Dept. of Civil Engg., Dayananda Sagar College of Engineering, Bengaluru-560078

Email Id: ranjitha-cvl@dayanandasagar.edu

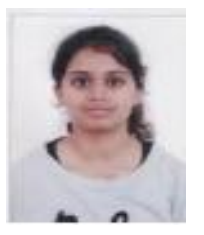

Ms. Kavya U S, 3rd year B.E. Student, Dept. of Civil Engg., Dayananda Sagar College of Engineering, Bengaluru- 560078.

Email Id: kavya.12nov95@gmail.com

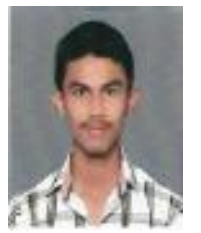

Mr. Puneeth B, 3 year B.E. Student, Dept. of Civil Engg., Dayananda Sagar College of Engineering, Bengaluru- 560078 Email Id: sbypuneeth@gmail.com 